\title{
Development and Implementation of Problem-based Chemistry Experiments for Engineering Students in a Multi-disciplinary Course
}

\section{Dr. Tiffany L. Hesser, University of New Haven}

Tiffany Hesser is a Senior Lecturer in the Engineering and Applied Science Education Department and the Chemistry and Chemical Engineering Department at the University of New Haven. With an M.S. in science education and an Ed.D. in educational leadership, her research efforts have been concentrated on technology integration, student learning with a strong focus on under-prepared student populations, and classroom design. She is the course coordinator for General Chemistry with Application to Biosystems in the Multidisciplinary Engineering Foundation Spiral Curriculum and is the Tagliatela College of Engineering Liaison for the Engineering and Science University Magnet School.

Ms. Stefanie R. Bunyea, MacDermid Enthone 


\title{
Development and Implementation of Problem Based Chemistry Experiments for Engineering Students in a Multi-Disciplinary Course
}

\begin{abstract}
This paper will describe the implementation and continuing development of five problem based laboratory experiments in a general chemistry course designed specifically for multiple disciplines of engineering students at the University of New Haven. The Problem Based Laboratory Experiments (PBLE) were developed to provide students with the opportunity to perform and develop experimental procedures working in interdisciplinary teams, while achieving a greater understanding of the role of chemistry in engineering fields.

In each PBLE, students first complete a traditional chemistry experiment to gain an understanding of the chemical concepts and to become familiar with executing a written procedure with a specific goal. Following this, students are presented with an engineering driven problem or task related to the chemical concepts. Students use knowledge obtained from the previously completed process to design an experiment addressing the problem.

In place of formal laboratory reports, students create technical memos, written by rotating team leaders, that includes their recommendations or responses to the presented problem. All recommendations must be based on their devised experimental approach and the actual data that was obtained. Students are also required to complete an error analysis by considering changes to improve data acquisition, should the experiment be run again. The technical memos are graded against a defined rubric that assesses the work with a focus on the designed experimental approach, data reporting and presentation, and recommendations based heavily upon those results. The grading is designed to allow students a level of academic freedom from right and wrong answers, focusing instead on understanding the value of working with data obtained from an experimental process and making recommendation based upon those results.

The development of skills needed to solve problems is important for both chemists and engineers. The problem based learning experience brought students beyond following simple protocols and procedures and gave students experience in an analytical design process, collaboration and technical writing. The goal of designing and implementing the PBLEs was to integrate a problem based learning experience while increasing levels of student engagement in comparison to more traditional chemistry experiments.
\end{abstract}

\section{Introduction}

Problem based learning is a learner-centered approach to instruction that encourages students to conduct research while integrating theory, knowledge and skills to develop a solution to a defined problem. ${ }^{1}$ Engineering instruction integrates well into problem based learning, allowing students real world problem solving experience in a classroom setting. It has been utilized in materials courses to examine material strengths and in mechanical engineering courses to examine system behavior and fluid dynamics. ${ }^{2,3}$ It has been utilized in chemistry instrumentation laboratories built around medical case analysis of drug analysis and quality controls in 
breweries. ${ }^{4}$ With its increasing use, students have benefit from the engaging scenarios, where learning gains have been found to be twice that of a traditional classroom setting. ${ }^{5}$

In addition to problem solving, collaboration is a key component as future engineers must be able to adopt strategies and tools for a multiple perspectives approach to better understand complex engineering problems. ${ }^{6}$ At the University of New Haven, engineering curriculum has been designed to support interdisciplinary learning with a multidisciplinary approach called The Spiral Curriculum. Unlike the traditional approach, the spiral curriculum introduces foundation courses with a mix of engineering topics including electrical circuits, fluid mechanics, heat transfer, material balances, properties of materials, structural mechanics and thermodynamics. The topics are presented in a variety of disciplinary contexts within the first two years of undergraduate education. A solid background is developed by touching key concepts at several points through the education process in different courses, adding depth and complexity at each pass. $^{7}$

General Chemistry with Application to Biosystems is a course developed specifically for engineers in the Spiral Curriculum. Developed in 2004, the goal was to introduce multiple disciplines of engineering students to quantitative and qualitative aspects of general chemistry, while examining its role in various biological systems. ${ }^{8}$ Past feedback from the course indicated that engineering students often had trouble appreciating the value of chemistry or biology in their educational experience. Therefore, the lecture portion of the course was further linked to examine chemical and biological ideas within other engineering topics.

Since the course's development in 2004, many of the laboratory experiments stemmed from a traditional General Chemistry 2 Laboratory. While some biological components were integrated, the overall structure of the class was similar to that of a chemistry laboratory, where a series of one-day experiments with multiple trials were done. The goal was to integrate the problem based learning approach to create an experimental process that would better align with what engineers might experience in other project based courses using a series of problem based learning experiments (PBLE) while increasing student engagement in comparison to traditional chemistry experiments.

\section{Laboratory Development}

The experimental topics were determined using previous chemistry experiments presented in the course. A team of teaching assistants, along with the course coordinator, developed an engineering driven problem to build off existing labs. These replaced the traditional chemistry labs as found in Table 1. 
Table 1. Comparison table of changes for PBLE implementation

\begin{tabular}{|c|c|c|}
\hline Week 1 & $\begin{array}{c}\text { Traditional Laboratory } \\
\text { Experiments }\end{array}$ & $\begin{array}{c}\text { Problem Based Laboratory } \\
\text { Experiments }\end{array}$ \\
\hline Week 2 & Fratistics and Experimentation & $\begin{array}{c}\text { Freezing Point Depression and } \\
\text { Examination Quality of Various Deicers }\end{array}$ \\
\hline Week 3 & Rates of Reaction & $\begin{array}{c}\text { Polymer Development and Examination } \\
\text { of Polymer/Initiator Ratios with Strength } \\
\text { Testing }\end{array}$ \\
\hline Week 4 & Temperature and Catalyst & $\begin{array}{c}\text { Solubility of Ionic Compounds Procedure } \\
\text { Examination of Removing Metal } \\
\text { Contamination from Water Sample }\end{array}$ \\
\hline Week 5 & Equilibrium Constant & $\begin{array}{c}\text { Examination of Chemical Versus } \\
\text { Week 6 }\end{array}$ Acid and Base Behavior \\
Week 7 & Acid-Base Behavior of Amino \\
Acids & Buffers & $\begin{array}{c}\text { Chemical Battery Procedure and } \\
\text { Examination of Varying Metals in } \\
\text { Batteries }\end{array}$ \\
\hline Week 9 & Dissolved Oxygen & $\begin{array}{r}\text { Week 10 } \\
\text { Biochemical Oxygen Demand }\end{array}$ \\
\cline { 1 - 2 }
\end{tabular}

Prior to leaving the laboratory on Week 1 , students are presented with the problem portion of the lab; a task or problem that they would need to solve in Week 2 . Students would then be required to design an experimental procedure in order to help answer the problem. Most of the PBLEs were developed so students could create a variation of the Week 1 procedure to develop a testing process for the Week 2 problem (Table 2).

The PBLEs were designed using a 2-week schedule for each experiment. Week 1 used an experimental process that would have been used in a traditional General Chemistry Laboratory, consisting of multiple trials using a step-by-step procedure. This gave students an understanding of what processes might be done in a lab with the given chemicals and glassware, as well as a specific set of knowledge and skills. 
Table 2. Problem Based Laboratory Overview By Experiment

\begin{tabular}{|c|c|c|c|c|}
\hline Experiment & Problem Presented & Week 1 Process & Week 2 Process & Chemical Concepts \\
\hline $\begin{array}{l}\text { Examination } \\
\text { Quality of Various } \\
\text { Deicers }\end{array}$ & $\begin{array}{l}\text { Recommend the } \\
\text { best de-icer that } \\
\text { your company } \\
\text { should use: } \\
\text { properties, cost, } \\
\text { environmental, etc. }\end{array}$ & $\begin{array}{l}\text { Determine the } \\
\text { freezing point } \\
\text { depression and } \\
\text { constant of } \\
\text { cyclohexane }\end{array}$ & $\begin{array}{l}\text { Develop a process to } \\
\text { evaluate the } \\
\text { effectiveness of } \\
\text { various de-icers } \\
\text { based on freezing } \\
\text { point depressions }\end{array}$ & $\begin{array}{l}\text { colligative properties, } \\
\text { intermolecular } \\
\text { forces, experimental } \\
\text { development }\end{array}$ \\
\hline $\begin{array}{l}\text { Examination of } \\
\text { Polymer/Initiator } \\
\text { Ratios with } \\
\text { Strength Testing }\end{array}$ & $\begin{array}{l}\text { Determine best } \\
\text { monomer to catalyst } \\
\text { ratio and synthesis } \\
\text { conditions to create } \\
\text { strongest polymer }\end{array}$ & $\begin{array}{l}\text { Synthesize polymer } \\
\text { Polycaprolactone } \\
\text { under various } \\
\text { conditions: time, } \\
\text { temp, monomer ratio }\end{array}$ & $\begin{array}{l}\text { Evaluate polymers } \\
\text { created with } \\
\text { qualitative and } \\
\text { quantitative tests }\end{array}$ & $\begin{array}{l}\text { intermolecular } \\
\text { forces, advanced } \\
\text { materials, } \\
\text { experimental } \\
\text { development }\end{array}$ \\
\hline $\begin{array}{l}\text { Examination of } \\
\text { Removing Metal } \\
\text { Contamination } \\
\text { from Water } \\
\text { Sample }\end{array}$ & $\begin{array}{l}\text { Remove heavy } \\
\text { metal contamination } \\
\text { from a water } \\
\text { samples }\end{array}$ & $\begin{array}{l}\text { Examine various } \\
\text { precipitation reactions } \\
\text { with solutions and } \\
\text { concentrations that } \\
\text { effectively remove } \\
\text { ions }\end{array}$ & $\begin{array}{l}\text { Develop a process } \\
\text { using precipitation } \\
\text { reactions to remove } \\
\text { unwanted ions out of } \\
\text { water, verifying } \\
\text { results }\end{array}$ & $\begin{array}{l}\text { precipitation } \\
\text { reactions, solutions, } \\
\text { spectroscopy, } \\
\text { experimental } \\
\text { development }\end{array}$ \\
\hline $\begin{array}{l}\text { Examination of } \\
\text { Chemical Versus } \\
\text { Biological Catalysts } \\
\text { Using Reaction } \\
\text { Rates }\end{array}$ & $\begin{array}{l}\text { Understand how } \\
\text { concentration of a } \\
\text { catalyst affects the } \\
\text { rate law of the } \\
\text { reaction, and which } \\
\text { catalyst is best }\end{array}$ & $\begin{array}{l}\text { Determine rate law of } \\
\text { the decomposition of } \\
\text { a reaction involving } \\
\text { hydrogen peroxide } \\
\text { and potassium iodide }\end{array}$ & $\begin{array}{l}\text { Determine rate law } \\
\text { of the decomposition } \\
\text { of hydrogen peroxide } \\
\text { and catalase }\end{array}$ & $\begin{array}{l}\text { rate of reactions, } \\
\text { mechanisms, } \\
\text { oxidation and } \\
\text { reduction, catalyst, } \\
\text { experimental } \\
\text { development }\end{array}$ \\
\hline $\begin{array}{l}\text { Examination of } \\
\text { Varying Metals } \\
\text { and Chemicals in } \\
\text { Batteries }\end{array}$ & $\begin{array}{l}\text { Find the best } \\
\text { combination of } \\
\text { anode/cathode to } \\
\text { give the highest } \\
\text { voltage output }\end{array}$ & $\begin{array}{l}\text { Understand how a } \\
\text { Galvanic Cell works, } \\
\text { and explore various } \\
\text { concentrations of } \\
\text { solutions }\end{array}$ & $\begin{array}{l}\text { Explore different } \\
\text { combinations of } \\
\text { metals and solutions } \\
\text { to make different } \\
\text { Galvanic Cells }\end{array}$ & $\begin{array}{l}\text { electrochemistry, } \\
\text { oxidation and } \\
\text { reduction, } \\
\text { experimental } \\
\text { development }\end{array}$ \\
\hline
\end{tabular}

\section{The Use of Technical Memos}

In industry, engineers possess the technical knowledge and are often relied on by members of a team or company to solve a problem. For this reason, engineers need to be able to properly communicate their thoughts and observations about the issue at hand. Technical writing and presentations are how engineers report out findings. The technical memo format adopted by the courses within the spiral curriculum at the University of New Haven are designed to instruct students on how to efficiently and effectively communicate these types of observations and solutions to issues. At the completion of each PBLE, students would also be expected to construct a technical memo presenting their findings.

Each new PBLE was first presented to the students using a technical memo. This allowed the material to be presented from the course instructor in the same format the students would eventually report their work. The technical memos delivered a series of information regarding the PBLE, included the overall problem and the question that would be addressed using a specifically designed experimental process. It also includes a large amount of background information regarding the topic in general and attachments (Figure 1). 


\begin{tabular}{|c|c|}
\hline \multicolumn{2}{|l|}{ To: Section $01,02,03,04$} \\
\hline EASC1121 Laboratory Coordinator & is a purer class of ethylene glycol that is most commonly used as a de-icer. The \\
\hline Subject: Freezing Point Lab Experiment & $\begin{array}{l}\text { cost of fluid varies widely due to market conditions. Ethylene glycol is effective to } \\
\text { well below } 0^{\circ} \mathrm{F} \text {. The amount deicing service companies charge end users is }\end{array}$ \\
\hline \multicolumn{2}{|r|}{ generally in the range of $\$ 8$ to $\$ 12$ per diluted gallon as a direct cost. Indirect costs } \\
\hline \multicolumn{2}{|l|}{$\begin{array}{l}\text { The objective of this project is to examine the freezing point property as it applies to } \\
\text { nonvolatile nonelectrolyte solutions and using this experience to create a more complex }\end{array}$} \\
\hline \multirow{2}{*}{$\begin{array}{l}\text { research experimentation process that examines the use of nonvolatile electrolyte } \\
\text { solutions and their effectiveness as road de-icers, in light of cost and environmental } \\
\text { concerns. }\end{array}$} & Urea: Urea currently is not in use as a road deicer, except in the State of \\
\hline & $\begin{array}{l}\text { Washington, but it is used on airport runways because it is less corrosive than } \\
\text { road salt to aluminum airplane bodies. Urea is an organic compound, which }\end{array}$ \\
\hline & degrades by hydrolysis to ammonia and then is converted to nitrate by soil \\
\hline \multirow{5}{*}{$\begin{array}{l}\text { Information on Freezing Point and Colligative Properties } \\
\text { The freezing point of a pure solvent is defined as the temperature at which the solid and } \\
\text { liquid phases are in dynamic equilibrium, i.e., the temperature at which melting of the } \\
\text { solid and freezing of the liquid occur at the same rate. For cyclohexane, this is shown in } \\
\text { equation form for the reaction below, where the double arrow signifies that the reaction } \\
\text { is reversible: }\end{array}$} & microorganisms. Although urea itself has relatively low toxicity in regards to \\
\hline & terrestrial and aquatic life are, ammonia and nitrate breakdown do potentially \\
\hline & pose environmental problems. The toxicity of ammonia alone to aquatic life is \\
\hline & $\begin{array}{l}\text { relatively high. One study finds that when exposed to as little as l-10 ppm of } \\
\text { ammonia, } 50 \text { percent of the aquatic biota present will die. The other by-product }\end{array}$ \\
\hline & of urea, nitrate, is basically a fertilizer and can potentially contaminate drinking \\
\hline$C_{6} H_{12(\text { liquid) }} \Leftrightarrow C_{6} H_{12(\text { solid) }}$ & \\
\hline \multirow{10}{*}{$\begin{array}{l}\text { When a nonvolatile solute is dissolved in a liquid solvent, several physical properties of } \\
\text { the pure solvent change; the boiling point of the solution is higher than that of the pure } \\
\text { solvent, the vapor pressure of the solvent in the solution is lower than that of the pure } \\
\text { solvent, and the freezing point of the solution is lower than that of the pure solvent. } \\
\text { These phenomena are known as colligative properties because their magnitude depends } \\
\text { on the number of solute particles in the solution. The vapor pressure lowering is related } \\
\text { to the mole fraction of solute particles present, while both the boiling point elevation } \\
\text { and the freezing point depression depend on the molality or concentration of the solute } \\
\text { particles in the solution. }\end{array}$} & drinking water impair the ability of humans to transport oxygen in the blood; this \\
\hline & is especially the case with infants and can result in methoglobinemia, or "blue \\
\hline & baby syndrome." Urea is effective to is effective to $25^{\circ} \mathrm{F} /-3^{\circ} \mathrm{C}$ and cost roughly 5 \\
\hline & times as much as rock salt as a direct cost. Indirect costs will vary. \\
\hline & \\
\hline & References \\
\hline & Department of Civil Engineering, University of Colorado at Denver (1994), \\
\hline & Environmentally Sensitive Sanding and Deicing Practices, Department of Transportation \\
\hline & Saliby, M.J., P.J. Desio, and G.L. Wheeler, Determination of Molecular Weight by Freezing \\
\hline & Point Depression, Experimental General Chemistry, $2^{\text {nd }}$ Ed., University of New Haven \\
\hline \multirow{7}{*}{$\begin{array}{l}\text { For a solution, the freezing point is the temperature at which the vapor pressure of the } \\
\text { solvent in the solution is equal to the vapor pressure of the pure solvent. This is so } \\
\text { because, when a solution freezes, only the solvent begins to solidify and the remaining } \\
\text { solution becomes more and more concentrated with solute. Since we know that the } \\
\text { vapor pressure of a solvent in a solution is lower than that of the pure solvent, the } \\
\text { temperature of the pure solvent must be lowered to that value at which its vapor } \\
\text { pressure is the same as that of the solvent in the solution. The net result is that the } \\
\text { solution has a lower freezing point than that of the pure solvent. }\end{array}$} & Press, West Haven, CT \\
\hline & $\begin{array}{l}\text { State of Michigan, Current Deicing Practices, www.michigan.gov/documents/ch2- } \\
\text { deice } 51438 \text { 7.pdf }\end{array}$ \\
\hline & Turunen, Markus (1997), Measuring Salt and Freezing Temperature on Roads, Meteorol. \\
\hline & Appl. 4,11-15 \\
\hline & Attachments \\
\hline & Day 1: Freezing Point Depression of Cyclohexane \\
\hline & Day 2: Experimentation of De-icing Solutions \\
\hline \multirow{2}{*}{$\begin{array}{l}\text { As mentioned earlier, the magnitude by which the freezing point is lowered depends on } \\
\text { the molality of solute particles in the solution. In equation form, this relationship is seen } \\
\text { below, where } \Delta \mathrm{T}_{\mathrm{f}} \text { is the freezing point depression, } \mathbf{K}_{\mathrm{f}} \text { is the freezing point depression }\end{array}$} & Analysis and Development of Technical Memo \\
\hline & Technical Memo Grading System \\
\hline
\end{tabular}

Figure 1. An example of the PBLE technical memo, first and last page

The attachments to the technical memo provided the Week 1 purpose and procedure, the Week 2 problem being addressed, an Analysis and Development handout for the development of the final report technical memo, and a rubric on how the process would be assessed. As previously addressed, traditional chemistry experiments were utilized for Week 1 to familiarize student with a process similar to what they might develop for their experimental design for Week 2 . The Week 2 attachment gave specifics in regards to notebook keeping and issues that needed to be considered as they worked through their design process (Figure 2). 


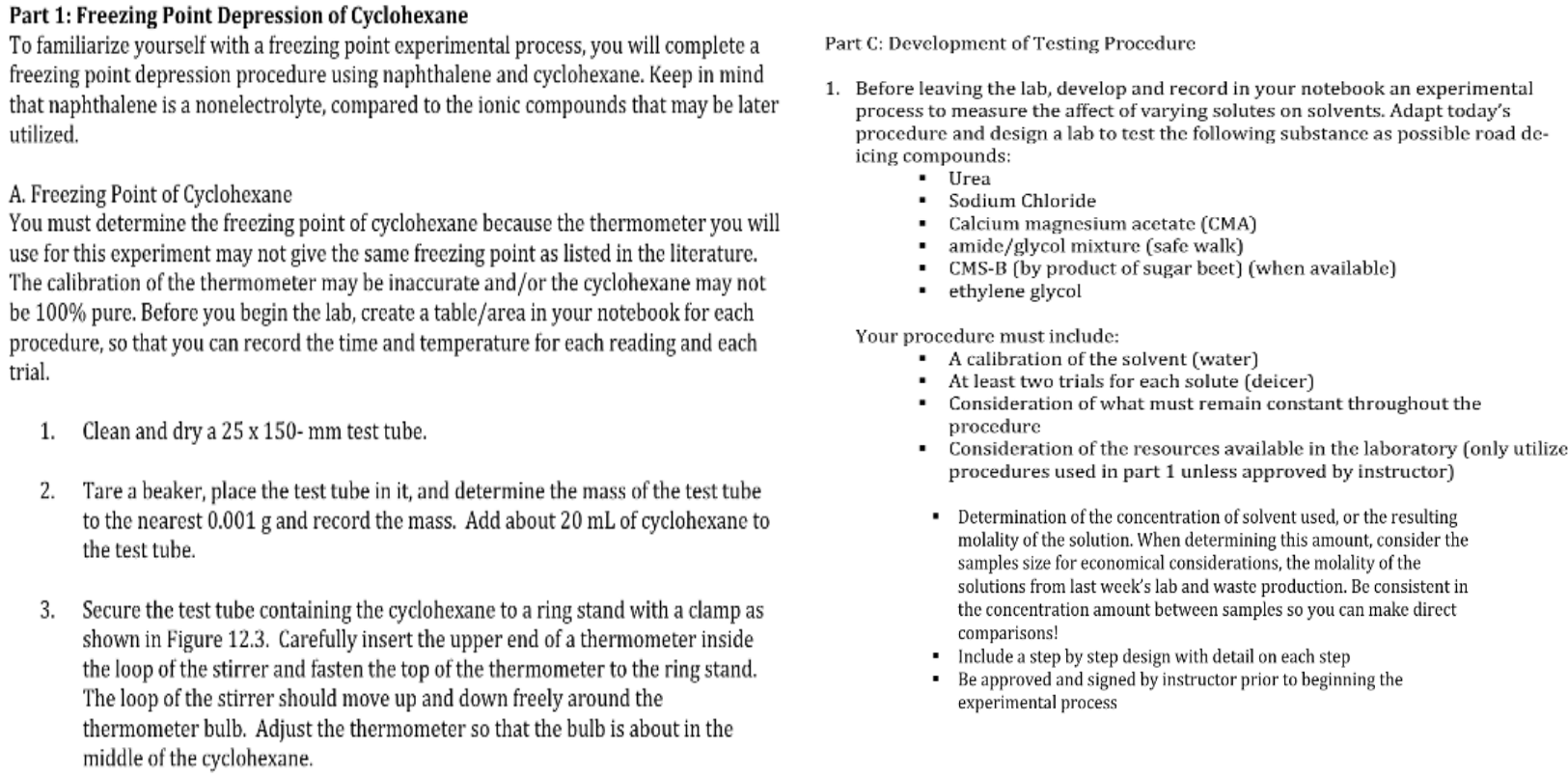

1. Clean and dry a $25 \times 150-$ mm test tube.

2. Tare a beaker, place the test tube in it, and determine the mass of the test tube to the nearest $0.001 \mathrm{~g}$ and record the mass. Add about $20 \mathrm{~mL}$ of cyclohexane to the test tube.

3. Secure the test tube containing the cyclohexane to a ring stand with a clamp as shown in Figure 12.3. Carefully insert the upper end of a thermometer inside the loop of the stirrer and fasten the top of the thermometer to the ring stand. The loop of the stirrer should move up and down freely around the thermometer bulb. Adjust the thermometer so that the bulb is about in the middle of the cyclohexane.

- Determination of the concentration of solvent used, or the resulting molality of the solution. When determining this amount, consider the samples size for economical considerations, the molality of the solutions from last week's lab and waste production. Be consistent in the concentration amount between samples so you can make direct comparisons!

- Include a step by step design with detail on each step

- Be approved and signed by instructor prior to beginning the experimental process

Figure 2. Examples of attachment including directions for Week 1 and Week 2

Traditional chemistry classes work with set chemical procedure and require formal laboratory reports that present a purpose, procedure, results and a discussion. Here, the development of technical memos by the students to report results better aligned with curricular expectation within the multidisciplinary courses and within industry. The final attachments addressed the technical memo, which were written by a "lead investigator" who compiled the information within the following sections:

- Proper headings including date, to, from and reason for the memo.

- Paragraph one should be a Summary Paragraph or a brief overview of the memo and include an objective of the experimental process and an initial summary of the results and recommendations.

- A Results section should have a summary table of data from your experimental trial labeled correctly and any relevant graphs that will aid in understanding your findings. All tables and graphs should be referenced in the body of the paper. This section should also identify your variables and your constants.

- Recommendations, which are based on the data you obtained, should address the questions regarding the problem. Your recommendations should take into consideration the findings, the cost and any additional concerns regarding environment or waste byproducts produced.

- Future Recommendations that address the limitations of your experimental process and recommends further/future testing based on those limitations.

- References that include this technical memo, your textbooks and any additional paper or Internet sources used.

- Attachments that includes copies of your experimental process from your lab notebook and all calculations attached to the technical memo and additional material you find useful 
Students were also given a rubric in the original document that would be used for evaluating the technical memos they created. The rubric contained criteria by which the technical memo would be evaluated by the course instructors and reminded students about required components and the overall scoring strategy (Figure 3). The grading is designed to allow students a level of academic freedom from right and wrong answers, focusing instead on understanding the value of working with data obtained from an experimental process and making recommendation based upon those results.

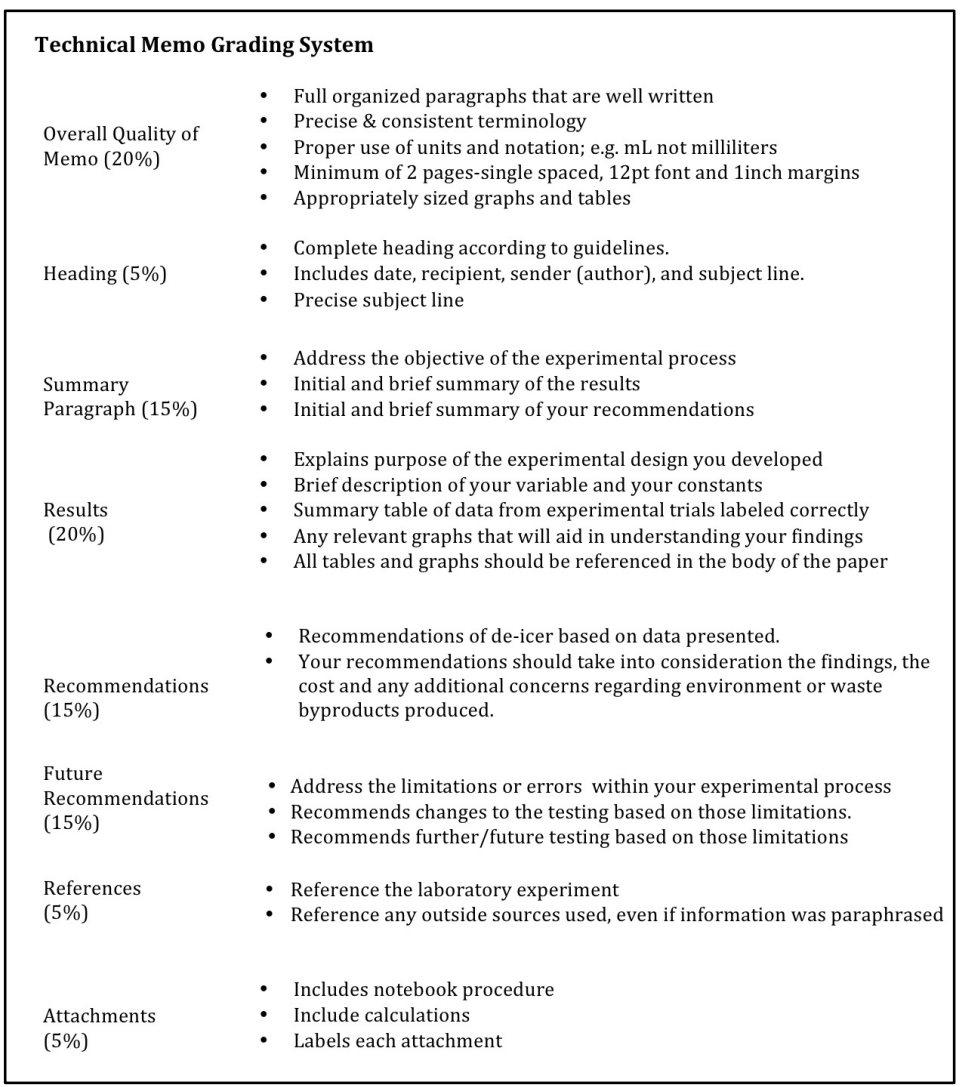

Figure 3. An example rubric used for technical memo evaluation

\section{Results}

Five new PBLEs were first introduced in 2014. The teaching assistants that developed the new labs were integrated into the course as laboratory assistants to allow for a seamless transition. The teaching assistants were aware of the overall goal of each lab, and helped direct the students and instructors through the lab. This allowed for each laboratory process to be examined for student and instructor clarity, in regards to the current materials. In addition, this allowed the teaching assistants to examine what worked and what would need altering for future semesters. Based on these interactions, changes were made to materials and adjustments were made to procedural components within the experimental process to ensure a more successful outcome in future labs. 
The distribution of students' primary majors during the two semesters can be found in Figure 4 . Of the student enrolled, 51 responded to the request to complete the online survey. Twenty-nine of those were enrolled in the course in the spring semester of 2014 and 22 in the spring semester of 2015.

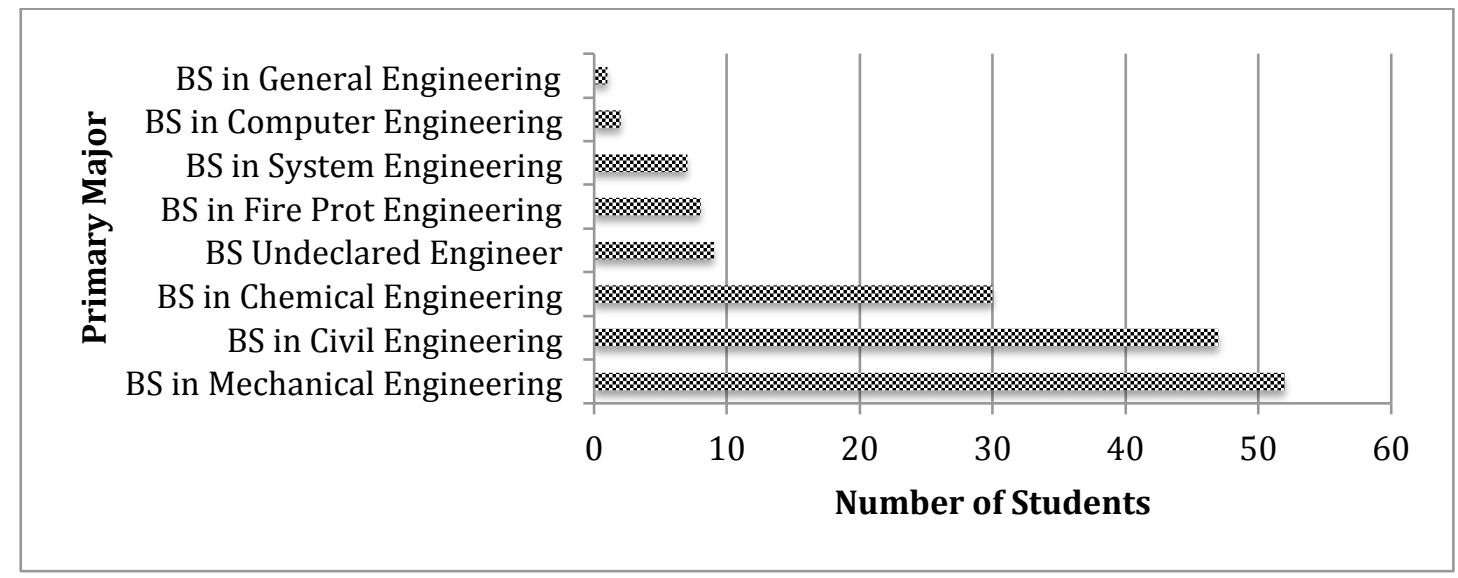

Figure 4. Student enrollment by major in spring 2014 and 2015

Students' responses to the PBLE integration were measured using engagement levels and openended response surveys. An online engagement survey allowed the students to provide feedback on questions regarding student engagement. The survey was developed using the National Survey of Student Engagement (NSSE) questionnaire, where specific questions were selected based on their measurability of relevance to the desired feedback at the classroom level. Only 14 questions were chosen from the NSSE questionnaire and three were added regarding feedback in comparison to previous laboratory experience.

The questions were combined into three grouping variables: collaborative learning, higher order thinking and personal skills development. A 1-4 scale (4 being associated with positive response) was used to quantify the responses. Originally, 14 questions were used to create the survey, but tests of reliability using SPSS showed low internal consistency and two questions were removed from the final analysis. This yielded a chronbach-alpha value of $0.758,0.780$ and 0.721 for the three grouping variables.

The results of the survey were then compared to the results supplied by the National Survey of Student Engagement using 2014 data results. Pairing questions from the two surveys using an independent t-Test with data made a comparison specific to those students earning a bachelors degree on the NSSE survey. It was found that students involved in PBLE had statistically significant higher averages when comparing cooperative learning variables, but was found to have the same averages statistically when examining higher-ordering thinking components and personal skills. (Table 3). 
Table 3. Mean and t-Test results from surveys

\begin{tabular}{|l|l|l|l|}
\hline $\begin{array}{l}\text { Grouping } \\
\text { Variable }\end{array}$ & $\begin{array}{l}\text { University } \\
\text { Average }\end{array}$ & $\begin{array}{l}\text { National BS } \\
\text { Average }\end{array}$ & $\begin{array}{l}\text { Independent } \\
\boldsymbol{t} \text {-Test Results }\end{array}$ \\
\hline Cooperative Learning & $3.222 \pm 0.4907$ & $2.749 \pm 0.1929$ & $t=17.3085, \mathrm{df}=13830, p<.001$ \\
\hline Higher Order Thinking & $2.931 \pm 0.1137$ & $2.945 \pm 0.0283$ & $t=3.4255, \mathrm{df}=12761, p<.001$ \\
\hline Personal Skills & $2.847 \pm 0.3247$ & $2.882 \pm 0.1881$ & $t=1.2821, \mathrm{df}=11014, p=0.1998$ \\
\hline
\end{tabular}

Three additional questions were asked on the survey specific to students enrolled this course and their experience with the PBLE labs. The percentage of the top responses for all survey questions (those scored with a 4 or 3 on the scale) can be seen in Table 4.

Table 4. Top responses for all survey questions

\begin{tabular}{|c|c|}
\hline Survey Questions (Often and Very Often Reponses) & \\
\hline $\begin{array}{l}\text { How often did you ask questions during laboratory or contribute to group discussions when } \\
\text { running or developing labs? }\end{array}$ & $90.2 \%$ \\
\hline How often did you work with others when running or developing labs? & $98.0 \%$ \\
\hline $\begin{array}{l}\text { In EASC1121 laboratory, how often did you work with others outside of class to complete an } \\
\text { assignment? }\end{array}$ & $98.0 \%$ \\
\hline $\begin{array}{l}\text { To what extent did your experience emphasize analyzing basic elements of an idea, experience } \\
\text { or theory such as specific case of experience in depth and considering its components? }\end{array}$ & $78.4 \%$ \\
\hline $\begin{array}{l}\text { To what extent did your experience emphasize synthesizing and organizing ideas, information, } \\
\text { experiences into new, more complicated interpretations and relationships? }\end{array}$ & $78.0 \%$ \\
\hline $\begin{array}{l}\text { To what extent did your experience in EASC } 1121 \text { PBL emphasize evaluating the value of } \\
\text { information, arguments or methods such as examining how others gathered and interpreted data } \\
\text { and access the accuracy of a conclusion? }\end{array}$ & $64.7 \%$ \\
\hline $\begin{array}{l}\text { To what extent did your experience emphasize applying theories and/or concepts to practical } \\
\text { problems or in new situations? }\end{array}$ & $78.4 \%$ \\
\hline $\begin{array}{l}\text { To what extent has your experience contributed to your knowledge, skills, and personal } \\
\text { development in acquiring job or career related knowledge and skills? }\end{array}$ & $52.9 \%$ \\
\hline $\begin{array}{l}\text { To what extent has your experience contributed to your knowledge, skills, and personal } \\
\text { development in writing clearly, accurately, and effectively with technical memo assignments? }\end{array}$ & $82.4 \%$ \\
\hline $\begin{array}{l}\text { To what extent has your experience contributed to your knowledge, skills, and personal } \\
\text { development in thinking critically and/or analytically? }\end{array}$ & $72.0 \%$ \\
\hline $\begin{array}{l}\text { To what extent has your experience contributed to your knowledge, skills, and personal } \\
\text { development in learning effectively on your own, so you can identify, research, and complete a } \\
\text { given task? }\end{array}$ & $54.0 \%$ \\
\hline $\begin{array}{l}\text { To what extent has your experience contributed to your knowledge, skills, and personal } \\
\text { development in working effectively with other individuals? }\end{array}$ & $78.4 \%$ \\
\hline $\begin{array}{l}\text { *The PBL labs gave me an appreciation for the role of chemistry in various engineering } \\
\text { disciplines. }\end{array}$ & $84.0 \%$ \\
\hline $\begin{array}{l}\text { *I found the application component of the problem based lab experiments more valuable to } \\
\text { learning than traditional general chemistry lab experiments. }\end{array}$ & $82.0 \%$ \\
\hline $\begin{array}{l}\text { *I believe the PBL experiments made the chemistry lab more interesting than traditional } \\
\text { chemistry experiments. }\end{array}$ & $89.8 \%$ \\
\hline
\end{tabular}

*Questions were not from the NSSE student engagement survey and were developed for the use of this study only 
Students were also offered a chance to share their open-ended feedback in regards to the advantages and disadvantage of the PBLE integrated into the course. Some feedback has been highlighted in Table 5.

Table 5. Open-ended student response to PBLE

Made you think outside the box. It gets pretty boring when you are given a procedure and you have to follow it. PBL gave us a chance to do what we wanted to do which made lab more enjoyable.

I felt like I had a better understanding of material when I left the lab.

It made you think critically about what was designed to be done*. It made you relate the first lab to a similar problem in the second lab while still having to think critically about what had to be done to be most successful.

This class seemed like the problems were more applicable to real life and $m u^{*}$ eventual job Experience more realistic engineering situations

We weren't really instructed on how to accomplish the procedure, so I very often had no idea how to create my own procedure.

It made it a bit more confusing to perform the lab.

* Quotes taken directly from surveys, errors in spelling, spacing or grammar remain

\section{Discussion}

The engagement surveys regarding the PBLEs indicate that the students believe that the PBLEs lent themselves to high interactive involvement between students. The cooperative learning and personal skills, while above average, did not differ from that of national averages for similar student groups. Responses show that $90 \%$ of students believe the PBLEs were more interesting than their traditional laboratory experience once semester prior. More telling were the opened ended responses, where students shared their ideas on how the labs enhanced their experience, but also often felt lost or confused at all the ideas and free-form processes within the PBLE. Overall, we believe the PBLE were well received by the students and are pleased with the survey results.

The introduction of five new laboratory experiments at once lead to obvious problems and necessary changes in the second year, as it can be difficult to anticipate issues that may arise during the implementation process. First, there were problems with the labs themselves. In the Examination Quality of Various Deicers experiment, students were asked to evaluate the effectiveness of various de-icers based on freezing point depressions. Within the PBLE, students had to develop an experimental process to test this using colligative property theories. We did not anticipate students using such high concentrations of deicers within their created solutions that we would not be able to create a set up where we could actually get the solution to freeze. In the Examination of Removing Metal Contamination from Water Sample experiment, students utilize precipitation reactions to remove heavy metal ions from contaminated water samples and samples were testing using a spectroscopy process. Again, we did not anticipate how thoroughly the metal would be removed once students overloaded samples with basic solution. Although ions were removed, $\mathrm{pH}$ levels were so high that the water samples would never be consumable, and therefore this PBLE was altered to include a $\mathrm{pH}$ component. Student will then be expected to balance those two variables for the most favorable outcomes. 
The initial reactions of students to the process were another difficulty that had not been anticipated. The technical memos were designed to allow students to act as consultants regarding their own experimental process and make recommendations based on their results; there was no wrong or right answer. This was concerning to students who believed that the instructors expected their results and responses to be the same as everyone else, when in fact, that is exactly the opposite of what we had hoped. We wanted them to learn that their procedure didn't work because they didn't consider an appropriate concentration; we wanted them to get results that were imperfect but still have to make recommendations based on the outcomes, while understanding why their process was flawed. This was more difficult for students at the beginning then previously expected, and required more instructor guidance.

Instructor guidance is actually the third place where problems arose. Without instructor guidance, problem-based learning can fail. ${ }^{1}$ The Week 2 portion of the experiment allowed freeform approaches to the problem solving process. Therefore, with approximately 20 students and 10 groups in each lab, this meant that the instructor was required to discuss, consider and direct students on the details of 10 different experimental procedures. This was a daunting task and required added effort by experienced teaching assistants and constant physical movement through the lab, to ensure that everyone was gaining the benefits of the problem based approach.

Finally, it was difficult to anticipate the timing of the PBLEs. Some of the labs took more time than we expected and had hoped for. Others could potentially be moved into one class period because the students moved through them so quickly. The experiments were adjusted in year two to account for some of these timing issues.

\section{Future Changes}

In an academic setting, laboratory and classroom lecture is constantly being adjusted to better fit the needs of the students and the knowledge that they are supposed to take from these interactions. Some of the issues previously discussed are still being addressed to better the course for the students.

To address one profound issue, the instructors and teaching assistants of the PBLEs should be given enhanced training to help them direct the students on what the goals of the labs are, and how to help them through the process. The key is to communicate this, but without telling them an "answer" on how to perform the experiment. We want the students to think about the issues, not just perform the actions to get a grade.

Some other thoughts to improve the course are ways to better engage the students to want to solve the problem. As we move ahead, it would be useful to obtain feedback from students to see if there are any specific topics that would be more interesting or better aligned with their outside coursework. These could then be developed into alternative PBLEs. It would also be interesting to find an issue that is currently pertinent to the students, where they could develop a passion for actually solving the problem.

This course is designed to help the students develop their technical writing professionally about actions and thoughts that they actually completed. However, many times, a professional engineer 
or scientist is verbally communicating their ideas and solutions in a meeting setting. One option is to take one PLBE technical memo and have the team verbally suggest their ideas and report their results to a professor or classmates for a separate grade.

\section{Conclusion}

The development of skills needed to problem solve is important for both chemists and engineers. The problem based learning experience brought students beyond following simple protocols and procedures and gave students experience in an analytical design process, collaboration and technical writing. The goal of designing and implementing the PBLEs was to integrate the problem based learning while increasing student engagement in comparison to traditional chemistry experiments. As discussed, issues did arise during the overall process but overall the PBLEs were well received by the students. The problem based learning experiments also encouraged students to consider the role of chemistry in engineering and better understand the complexities of the experimental design process.

\section{References}

1. Savery, J. R. (2006). Overview of problem-based learning: Definitions and distinctions. Interdisciplinary Journal of Problem-Based Learning , 1 (1), 9-20.

2. Baharom, S., Hamid, R., \& Hamzah, N. (2012). Development of a problem based learning in concrete technology laboratory work. Procedia - Social and Behavioral Sciences , 60, 8-13.

3. Sundarajan, S., Faidley, L., \& Meyer, T. (2012). Developing inquiry-based laboratory exercises for a mechanical engineering curriculum. Mechanical Engineering Conference, American Society of Engineering Education.

4. Robinson, J. K. (2013). Project-based learning: Improving student engagement and performance in the laboratory. Analytical and Bioanalytical Chemistry , 405, 7-13.

5. Yadav, A., Subedi, D., Lundeberg, M., \& Bunting, C. (2011). Problem based learning: Influence on students' learning in an electrical engineering course. Journal of Engineering Education, 100 (2).

6. Adams, R., Evangelou, D., English, Lyn, Dias De Figueiredo, A., Mousoulide, N., Pawley, A., et al. (2011). Multiple Perspectives on Engaging Future Engineers. Journal of Engineering Education , 100 (1), 48-88.

7. Collura, M., Daniels, S., Nocito-Gobel, J., \& Harding, W. (2007). The current generation of integrated engineering curriculum - Assessment after two years of implementation. American Society of Engineering Education.

8. Harding, W., Schwartz, P., Nocito-Gobel, J., \& Koutsospyros, A. (2007). A hybrid first year science course for engineering students - Integrating biology with chemistry. American Society of Engineering Education. 